\title{
Pharmaceutical equivalence study of amoxicillin/clavulanic acid salt tablets commercially available in UAE pharmaceutical market
}

\author{
Fazilatun Nessa ${ }^{*}$, \\ Hibatullah Al Zoubi2 \\ Gazala Afreen Khan ${ }^{3}$ \\ ${ }^{1}$ Deaprtment of Pharmaceutical \\ Chemistry \& Natural Products, Dubai \\ Pharmacy College for Girls, Dubai, UAE \\ ${ }^{2}$ MPharm Student of Pharmaceutical \\ Product Development, Dubai Pharmacy \\ College for Girls, Dubai, UAE \\ ${ }^{3}$ Department of Pharmaceutics, Dubai \\ Pharmacy College for Girls, Dubai, UAE
}

*Corresponding author:

Fazilatun Nessa

dr.fazilatun@dpc.edu

\section{KEYWORDS:}

Pharmaceutical equivalence; Amoxicillin; Clavulanic acid salt

\begin{abstract}
Pharmaceutical equivalence in terms of physicochemical parameters and antimicrobial susceptibility/resistance of ten commercial products of UAE containing amoxicillin and clavulanic acid salts were evaluated to determine their level of compliance to the official monograph requirements. A validated RP-HPLC method was used for quantification of active pharmaceutical ingredients according to United State Pharmacopeia 40-National Formulary-35. The system suitability study indicated the retention times and peak areas were reproducible and were suitable for the identification and quantification of amoxicillin/clavulanic acid salts within tablets of studied products. The physical parameters test results as hardness, friability, weight variations and disintegration times were also within ranges and complied with the official monographs. The rate of dissolution of amoxicillin and clavulanic acid salts from tablet dosage form in $30 \mathrm{~min}$ was within United State Pharmacopeia 40-National Formulary-35 limits. The dissolution profiles were compared with a reference product, using eight data points. The similarity factor $(f 2)$ and difference factor $(f 1)$ were calculated and the results indicated that all the products were 50$51 \%$ similar with the reference product. The $f 1$ were also below $15 \%$ except a product's clavulanic acid content. The antimicrobial susceptibility/resistance study results showed that all the products were active against Escherichia coli, Staphylococcus aureus and Streptococcus pneumonia except Pseudomonas aeruginosa, which was resistant to amoxicillin/clavulanic acid salt. The minimum inhibitory concentration and minimum bacterial concentrations against these bacteria were also determined using broth dilution method. In conclusion, this study indicated all the studied products were pharmaceutically equivalent in respect of physicochemical parameters and antimicrobial activity.
\end{abstract}

\section{INTRODUCTION}

Amoxicillin belongs to the penicillin-like antibiotics class, works by inhibiting the growth of bacteria ${ }^{1}$. On the other side clavulanic acid belongs to beta-lactamase inhibitors, which acts by preventing bacteria from destroying the action of amoxicillin ${ }^{2}$. The combination of amoxicillin and clavulanic acid which has been 
reported to give good results in clinical use as broad spectrum antibiotics rather than single one ${ }^{3-6}$. This combinations are used in the treatment of certain bacterial infections such as infections in skin, lungs, ears, sinus and urinary tract ${ }^{7-10}$. Globally a number of pharmaceutical company manufacture and marketed this combined dosage form. Before launching any products, pharmaceutical company follows certain quality control guidelines to ensure the quality of the manufactured products. Once the products come to the market, the quality of the products can be affected with the environmental conditions as during transportation and storage conditions. Therefore, evaluation of the quality of marketed products is an ongoing process. Drug products are called pharmaceutically equivalent when the products contained same active ingredient, identical dosage form, route of administration and strength respectively but drug products may differ in excipients, release mechanisms, packaging, shape, expiration time and labeling ${ }^{11}$. To know the pharmaceutical equivalence of different products, it is important to evaluate quality control parameters of marketed products that will reflects the quality of generic and innovator products. Quality of the product can be assessed by evaluation of the physicochemical characteristics of tablets such as dimensions measurements, weight variation of individual tablets, loss in friability, test for hardness, assay and dissolution rate of the products using pharmacopoeial standards as well as antibacterial studies like susceptibility test, minimum inhibitory concentrations and minimum bacterial concentrations against specific microorganisms. The study protocol need to be validated to obtain accurate and precise results. Researcher from different countries studied on the combination of amoxicillim/clavulanic acid products regarding physiochemical properties and antimicrobial activity of local and imported products, there were not much deviations between the innovator and studied brands in respect of investigation of many specific parameters ${ }^{12-15}$.

In United Arab Emirates (UAE), majority of pharmaceutical products are imported from around the globe with the permission of Ministry of Health ${ }^{16}$. Therefore, the local market is dominated by patented drugs which are higher in cost than local product as only 5-6\% generics products are available in $\mathrm{UAE}^{17}$. There are three different strengths as $875 / 125 \mathrm{mg}, 500 / 125 \mathrm{mg}$ and $250 / 125 \mathrm{mg}$ tablet dosage form containing amoxicillin/clavulanic acid salt combinations are available in UAE pharmaceutical markets. In addition, this combinations are also available as dry powder for oral suspension, extended release tablet and chewable tablet respectively. Based on the most commonly prescribed strength this study was designed with the aim of to evaluate pharmaceutical equivalence according to USP official monograph ${ }^{18}$ of some brands of medicinal agents containing amoxicillin and clavulanic acid salts (500/125mg) those are available in UAE Pharmaceutical Market.

\section{MATERIALS AND METHODS}

\subsection{Materials for physical and chemical analysis}

USP Reference Standard (RS) Amoxicillin and Clavulanate lithium were obtained as a gift sample from MedPharma UAE. AR grade monobasic sodium phosphate and phosphoric acid (85\%) were supplied by SigmaAldrich (USA). HPLC grade methanol were provided by Fisher Biotech (USA). Buffer solution $\mathrm{pH}: 7.01$ and $\mathrm{pH}$ : 4.01 were manufactured by Hanna instruments (Italy). All glassware and ceramics were of Pyrex grade. Disposable Thermo Scientific PVDF syringe filters $(0.45 \mu \mathrm{m})$ were supplied by Fisher Scientific (UK). Milli-Q Ultrapure (Type 1) water (Millipore, Bedford, MA, USA) was used for preparation of sample and standard solutions as well as mobile phase for HPLC analysis.

\subsection{Materials for microbiological studies}

Two gram negative bacteria Escherichia coli (ATCC $\AA 25922^{\mathrm{TM}}$ ) and Pseudomonas aeruginosa (ATCC ${ }^{\circledR} 27853^{\mathrm{TM}}$ ) and two gram positive bacteria Staphylococcus aureus (ATCC25923) and Streptococcus pneumonia (ATCC® $49619^{\mathrm{TM}}$ ) were acquired from Rashid Hospital Microbial Culture Collection unit (RHCC), Rashid Hospital, Dubai, UAE. All the Microbiological culture media used in the study such as Nutrient agar, Mac-Conkey Agar, Blood Agar and Mueller Hilton broth were obtained from Himedia laboratories (USA). Barium Chloride and Sulphuric acid was also provided by Himedia laboratories (USA). Milli-Q Ultrapure (Type 1) water was used throughout the study.

\subsection{Sample description}

Ten different brands of tablets that contained amoxicillin-500 mg and clavulanic 
acid salt-125 $\mathrm{mg}$ were purchased from pharmacies of UAE. Amongst the investigated products four products were manufactured in UAE and the remaining six products were imported from UK, Austria, India, Jordan, KSA and Switzerland respectively. The products were coded as AU (UK), CU (Austria), CL (UAE), JU (UAE), GL (UAE), SW (India), AM (Jordan), ME (KSA), NE (UAE) and AP (Switzerland) respectively.

\subsection{Determination of physical parameters}

The determination of the physical parameters of ten brands of tablets were conducted. Weight variation test was carried out with 20 tablets using an analytical balance and the results were expressed as average weight (mg) \pm standard deviation (SD). The lengths of 20 tablets for each brand expressed as average dimension $(\mathrm{mm}) \pm \mathrm{SD}$ were measured using a micrometer. Hardness test was carried out using Erweka hardness tester (Germany) and the results were expressed in $\mathrm{kg} \pm \mathrm{SD}$. Friability of a tablets were measured with using a Friability test apparatus manufactured by Grover Enterprises (India) operated at $25 \mathrm{rpm}$ for $4 \mathrm{~min}$ and the results were expressed as percent loss. Disintegration of tablets was carried using Tablet Disintegration Tester (India) where the temperature of water was maintained at $37^{\circ} \mathrm{C} \pm$ $2^{\circ} \mathrm{C}$. The disintegration time for each tablet was recorded and expressed in min.

\subsection{Preparation of standards and sample solutions}

\subsubsection{Preparation of standards}

For quantitative analysis, $500 \mu \mathrm{g} / \mathrm{ml}$ amoxicillin and $200 \mu \mathrm{g} / \mathrm{ml}$ clavulanate lithium salt solution were prepared with Milli-Q water into a $10 \mathrm{ml}$ volumetric flask, whereas for identification purposes the standard solutions were prepared separately ${ }^{18}$.

\subsubsection{Preparation of samples}

The samples were prepared according the procedure described by USP-NF ${ }^{18}$. The mean product weight of 10 tablets for each sample was determined and were ground into a fine powder. The powdered tablets in three replicates for each sample were weighed accurately. Each portion of samples contained equivalent amounts of 0.5 $\mathrm{mg} / \mathrm{ml}$ of amoxicillin and $0.2 \mathrm{mg} / \mathrm{ml}$ of clavulanate salt respectively. The samples were then mixed with $100 \mathrm{ml}$ Milli-Q water and stirred for 15 min with the aid of magnetic stirring to dissolve the drugs into water. The sample solutions were filtered through a Whatman No.42 filter paper and $0.45 \mu \mathrm{m}$ membrane filter before HPLC analysis. The prepared sample solutions were injected into the HPLC system within $1 \mathrm{~h}$.

\subsection{HPLC instrumentation}

Water HPLC Instrument, binary gradient pump equipped with UV-VIS detector, autosampler and Breeze-2 HPLC Systems was used for carrying out the HPLC analysis. Buffer (pH 4.40) was prepared using monobasic sodium phosphate in Milli-Q Ultra water and adjusted the required $\mathrm{pH}$ with phosphoric acid. The mobile phase consisted of buffer and methanol $(19: 1 \mathrm{v} / \mathrm{v})$ was filtered through $0.45 \mu \mathrm{m}$ membrane filter and degassed prior to use. The HPLC analysis was carried out using Water Symmetry ${ }^{\circledR}$ RP C18 column $(75 \times 4.6 \mathrm{~mm}, 3.5 \mu \mathrm{m}$ particles $)$ with isocratic mode. The mobile phase flow rate was $1 \mathrm{ml} / \mathrm{min}$ and the sample run time was $8 \mathrm{~min}$. The detection wavelength was set at $220 \mathrm{~nm}$ and the column ambient temperature was $25^{\circ} \mathrm{C}$.

\subsection{HPLC method validation}

\subsubsection{Calibration curves and ranges}

The standard stock solutions that contained $500 \mu \mathrm{g} / \mathrm{ml}$ amoxicillin and $200 \mu \mathrm{g} / \mathrm{ml}$ clavulanic acid salt, further diluted with Milli-Q water to prepare working standard solutions in ranges of 1 to $250 \mu \mathrm{g} / \mathrm{ml}$ for amoxicillin and 0.4 to $100 \mu \mathrm{g} / \mathrm{ml}$ for clavulanic acid salt respectively. $20 \mu \mathrm{l}$ of different concentration was injected in triplicates into HPLC system for each concentration. Calibration curves were constructed using eight data points to obtain slope, intercept and correlation coefficient for each drug.

\subsubsection{System suitability, intra-day and day to day precision}

The suitability of the HPLC-system was evaluated by injecting $20 \mu \mathrm{l}$ of three different concentrations of reference standard solutions that contained 100, 250 and $500 \mu \mathrm{g} / \mathrm{ml}$ amoxicillin and 40, 100 and $200 \mu \mathrm{g} / \mathrm{ml}$ (clavulanic acid salts) respectively. The injection was repeated for ten 
times for each concentration. For intra-day precision, four different concentrations were injected into the HPLC system on the same day as: $1 \mu \mathrm{g} / \mathrm{ml}$ (amoxicillin) $/ 0.4 \mu \mathrm{g} / \mathrm{ml}$ (clavulanic acid salts), $100 \mu \mathrm{g} / \mathrm{ml}$ (amoxicillin) $/ 40 \mu \mathrm{g} / \mathrm{ml}$ (clavulanic acid salts), $250 \mu \mathrm{g} / \mathrm{ml}$ (amoxicillin) $/ 100$ $\mu \mathrm{g} / \mathrm{ml}$ (clavulanic acid salts), and $500 \mu \mathrm{g} / \mathrm{ml}$ (amoxicillin) $/ 200 \mu \mathrm{g} / \mathrm{ml}$ (clavulanic acid salts) respectively. For day to day precision study, the test was repeated for 5 days. The injections were repeated three times for each concentration. The deviation of results were expressed as peak area \pm standard deviation. The value in percent relative standard deviation (\%RSD) was also calculated for each concentration.

\subsubsection{Limit of detection (LOD) and limit of quantification $(L O Q)$}

LOD and LOQ for amoxicillin and clavulanate salt were determined by injecting various concentrations of standard solutions into the HPLC system under same experimental conditions. They were determined based on the signal to- noise method.

\subsubsection{Recovery}

The accuracy of analytical method was determined by recovery study. In this study a definite concentration of standard solutions as 100,250 and $500 \mu \mathrm{g}$ amoxicillin and 40, $100 \&$ $200 \mu \mathrm{g}$ clavulanic acid salts were added to an equivalent amounts of powdered samples and then samples were prepared according to the assay sample preparation. The blank samples were prepared without added standards. The recovery of added drugs was then determined by subtracting the results of samples with standards from corresponding blanks sample.

\subsection{In vitro dissolution study and comparison of dissolution profiles}

Dissolution of different brands of amoxicillin and clavulanate salts tablets were carried out using USP Apparatus II (Paddle) with $900 \mathrm{ml}$ water as dissolution medium with paddle speed $75 \mathrm{rpm}$ according to USP-NF ${ }^{18}$. Nine units of each brand were used in this study. The sample solutions $(5 \mathrm{ml})$ were withdrawn at $0,5,10,15$, 20, 30, 40, 50 and $60 \mathrm{~min}$ time intervals. The withdrawn volume was replaced with Milli-Q water to maintain water volume $900 \mathrm{ml}$. The collected samples solutions (triplicates) were filtered through a $0.45 \mu \mathrm{m}$ membrane filter and immediately analyzed by RP-HPLC system. The cumulative percentages of drug release from different dosage forms were plotted against time (min) to generate dissolution profiles for each drug separately.

The dissolution profiles of amoxicillin and clavulanate salts tablets were compared based on model-independent methods proposed and described by Moore and Flanner ${ }^{19}$. In this method, a product $\mathrm{AU}$ (UK) was considered a reference and the remaining 9 products were considered as test products where, several time points were generated and they can be considered similar based on overall profile similarity or similarity at every time point. Two factors namely $f 1$ - is known as difference factor was calculated using the formula as $f l=\{[\Sigma \mid \mathrm{Rt}-\mathrm{Tt}$ | ]/[ $\Sigma \mathrm{Rt}]\} \times 100$ and $f 2-$ is called similarity factor were calculated using the formula: $f 2=50$ $\mathrm{x} \log \left\{\left[1+(1 / \mathrm{n}) \Sigma(\mathrm{Rt}-\mathrm{Tt})^{2}\right]^{-0.5}\right\} \times 100$, where, $\mathrm{n}$ : is the number of sample time points, Rt: is the \% dissolution value of the reference product at sample time point's $\mathrm{t}$, and $\mathrm{Tt}$ : is the $\%$ dissolution value of the test product at sample time point's $t$. The dissolution profiles curve for reference and test products are considered similar if $f 1$ values close to 0 and $f 2$ values close to 100 . Generally, the ranges for $f 1$ value are $0-15$ and for $f 2$ value is $50-100$ respectively.

\subsection{Methods for microbiological studies}

\subsubsection{Preparation of media}

For inoculation, sub-culturing of bacteria and Minimal Inhibitory Concentration (MIC), determination Mueller Hinton broth was prepared $(21 \mathrm{~g} / \mathrm{l})$ in water. $4 \mathrm{ml}$ each of prepared Mueller Hinton culture broth was transferred to numerous test tubes and autoclaved at $121^{\circ} \mathrm{C}$ for $15 \mathrm{~min}$ at $15 \mathrm{lb}$ pressure ${ }^{20}$. Nutrient agar was prepared $(28 \mathrm{~g} / \mathrm{l})$ in water and used for the subculturing of organisms $S$. aureus and $P$. aeruginosa and for determination of Minimal Bactericidal Concentration (MIB). Mac-Conkey agar $(49.53 \mathrm{~g} / \mathrm{l})$ in water was prepared and used for sub-culturing gram negative organism E.Coli. For sub-culturing of S. pneumonia blood agar (28 $\mathrm{g} / \mathrm{l}$ water) was prepared. All the prepared media were autoclaved at $121^{\circ} \mathrm{C}$ for $15 \mathrm{~min}$ at $15 \mathrm{lb}$ pressure ${ }^{20}$. The prepared blood agar base was further cooled to $50^{\circ} \mathrm{C}$ and then $5 \%(\mathrm{v} / \mathrm{v})$ sterile defibrinated blood was added that was cooled to room temperature and mixed gently. 


\subsubsection{Antibiotic standard and sample preparation}

A stock solution antibiotic standards that contained $500 \mu \mathrm{g} / \mathrm{ml}$ amoxicillin and $200 \mu \mathrm{g} / \mathrm{ml}$ clavulanic acid salt was prepared according to section 2.5.1 ${ }^{18}$. Further a one fold dilution approach was used to prepare different concentrations of amoxicillin $(250,125,62.5$, $31.25,15.63,7.82,3.91,1.955,0.9775,0.48875$ and $0.244375 \mu \mathrm{g} / \mathrm{ml}$ ) and clavulanic acid salt $(100,50,25,12.5,6.25,3.125,1.56,0.78,0.39$, 0.195 and $0.0975 \mu \mathrm{g} / \mathrm{ml}$ ) respectively for MIC and MBC determination. The antibiotic tablet sample solution was prepared according the method described in subheading 2.5.2. The one fold dilution procedure was also employed for all studied brands of tablets.

\subsubsection{Antibiotic susceptibility testing}

The antibiotic susceptibility testing was performed using the well diffusion method. For inoculum preparation, the isolated sub cultured bacterial strains of E. coli, S. pneumonia, S. aureus and $P$. aeruginosa were added to the separate test tubes containing Mueller Hinton broth. The inoculated culture broth tubes were then incubated at $37^{\circ} \mathrm{C}$ for $8 \mathrm{~h}$ and compared the turbidity with $0.5 \mathrm{McFarland}$ standard that corresponding to bacterial population approximately $10^{8}$ colony forming unit(CFU)/ml using UV-spectrophotometer. The test was then performed by applying a bacterial inoculum of approximately $2 \times 10^{8} \mathrm{CFU} / \mathrm{ml}$ to the surface of a large (150 $\mathrm{mm}$ diameter) Nutrient agar petriplate by using the pour plate technique ${ }^{21}$. The diameter of the well was $7 \mathrm{~mm}$ and $50 \mu \mathrm{l}$ of the antibiotic solutions were added to the well then the plates were incubated at $37^{\circ} \mathrm{C}$ for $24 \mathrm{~h}$. For $P$. aeruginosa incubation was continued for $48 \mathrm{~h}$. Water was used as blank solution. The zone sizes were measured in $\mathrm{mm}$ with a Kirby Baeur standard scale. Each sample was repeated for three time and the results were expressed as \pm SD (standard deviation). The reference standards were tested along with samples solution.

\subsubsection{MIC and MBC determination}

MIC and MBC were determined by broth dilution method as reported earlier ${ }^{22-24}$. Inoculum was acquired from an overnight nutrient agar subculture of the experimental organism. Inoculum was prepared by using three to five well-isolated colonies of the same morphology from an agar plate culture. The top of each colony was touched with a sterile loop and the bacterial colonies was transferred into a tube containing 5 $\mathrm{ml}$ nutrient broth and incubated at $37^{\circ} \mathrm{C}$ until it achieved the turbidity of the 0.5 McFarland standards correspond to bacterial population of approximately $10^{8} \mathrm{CFU} / \mathrm{ml}$. From this, $0.5 \mathrm{ml}$ of bacterial culture and $4 \mathrm{ml}$ Mueller Hinton Broth was added to $0.5 \mathrm{ml}$ of different concentrations of drug and incubated for $24 \mathrm{~h}$ at $37^{\circ} \mathrm{C}$ to determine MIC. MIC was taken as the least concentration that inhibited discernible bacterial growth in the dilutions. All the test tubes that showed no visible growth in the MIC test were cultured on nutrient agar plates and incubated at $37^{\circ} \mathrm{C}$ for $18-24 \mathrm{~h}$. The lowest concentration that inhibited $99.9 \%$ of growth on the nutrient agar plate was documented as the $\mathrm{MBC}^{25}$.

\subsection{Statistical analysis}

The statistical analysis of data were carried out using IBM SPSS Statistics (Verson 23). One-way ANOVA (Analysis of Variance) and Tukey's test were $(\mathrm{p}<0.05)$ were performed for multiple comparison.

\section{RESULTS AND DISCUSSION}

\subsection{Determination of physical parameters of tablets}

The average tablet weights of ten different brands were ranged from $967.42 \mathrm{mg}$ (CU) to $1264.90 \mathrm{mg}$ (AM). According to USP$\mathrm{NF}^{18}$ only $\pm 5 \%$ weight variation is accepted for dietary supplement tablets having average weight about $325 \mathrm{mg}$ or above, as well as Pharmaceuticals manufacturing company also follows the same criteria. Weight variation test is also used for checking content uniformity if tablet contains $25 \mathrm{mg}$ or more of an active drug ${ }^{18}$, hence weight variation test results indicated that the individual tablet weight variation was less than $\pm 5 \%$ and all the products passed the weight variation test. The average tablet weight of test products and their weight variation ranges in percent from average are presented in Table 1. The lengths of twenty tablets for each brand of tablets were measured. The recorded ranges were $21.71 \mathrm{~mm}$ (CU) to $23.30 \mathrm{~mm}$ (CL). Tablet hardness or Tablet Breaking Force is a very important quality control parameter and the accepted values for hardness of tablets are 4 to 10 
Table 1. The recorded physical parameters of ten different brands of tablets that contained amoxicillin and clavulanic acid salts $(500 / 125 \mathrm{mg})$.

\begin{tabular}{ccccccc}
\hline $\begin{array}{c}\text { Tablet Brands } \\
\text { Name }\end{array}$ & $\begin{array}{c}\text { Tablet weight } \\
\text { mg } \pm \text { SD }\end{array}$ & $\begin{array}{c}\text { Weight } \\
\text { Variation } \\
\text { Range (\% from } \\
\text { Average) }\end{array}$ & $\begin{array}{c}\text { Length } \\
\text { mm } \pm \text { SD }\end{array}$ & $\begin{array}{c}\text { Hardness } \\
\text { kg } \pm \text { SD }\end{array}$ & $\begin{array}{c}\text { Friability } \\
\text { \%loss } \pm \text { SD }\end{array}$ & $\begin{array}{c}\text { Disintegration } \\
\text { Time } \\
\text { min } \pm \text { SD }\end{array}$ \\
\hline AP(Switzerland) & $1148.39 \pm 11.94$ & $99 \%-101 \%$ & $22.21 \pm 0.37$ & $9.29 \pm 0.34$ & $0.14 \pm 0.00$ & $3.20 \pm 0.26$ \\
CL (UAE) & $1144.53 \pm 22.36$ & $98 \%-102 \%$ & $23.30 \pm 0.39$ & $9.21 \pm 0.15$ & $0.19 \pm 0.00$ & $3.27 \pm 0.31$ \\
GL (UAE) & $1068.39 \pm 11.05$ & $99 \%-101 \%$ & $22.23 \pm 0.25$ & $9.25 \pm 0.16$ & $0.23 \pm 0.01$ & $3.37 \pm 0.21$ \\
AU (UK) & $1068.54 \pm 9.82$ & $99 \%-101 \%$ & $22.39 \pm 0.37$ & $9.45 \pm 0.17$ & $0.20 \pm 0.00$ & $3.23 \pm 0.25$ \\
CU (Austria) & $967.42 \pm 10.71$ & $99 \%-101 \%$ & $21.71 \pm 0.29$ & $8.37 \pm 0.23$ & $0.35 \pm 0.01$ & $3.10 \pm 0.10$ \\
ME (KSA) & $1005.89 \pm 14.25$ & $99 \%-101 \%$ & $22.12 \pm 0.22$ & $9.32 \pm 0.18$ & $0.16 \pm 0.00$ & $3.12 \pm 0.10$ \\
NE (UAE) & $1145.22 \pm 13.71$ & $99 \%-101 \%$ & $22.39 \pm 0.28$ & $9.27 \pm 0.12$ & $0.19 \pm 0.00$ & $3.30 \pm 0.30$ \\
SW (India) & $1136.08 \pm 10.22$ & $99 \%-101 \%$ & $22.68 \pm 0.27$ & $9.37 \pm 0.14$ & $0.17 \pm 0.00$ & $3.13 \pm 0.15$ \\
JU (UAE) & $1101.03 \pm 15.03$ & $99 \%-101 \%$ & $22.60 \pm 0.35$ & $9.72 \pm 0.17$ & $0.12 \pm 0.00$ & $3.27 \pm 0.21$ \\
AM (Jordan) & $1264.87 \pm 19.96$ & $98 \%-102 \%$ & $22.32 \pm 0.22$ & $9.26 \pm 0.11$ & $0.14 \pm 0.00$ & $3.70 \pm 0.26$ \\
\hline
\end{tabular}

kg. All the studied products exhibited hardness near to the upper value as $8.37 \mathrm{~kg}(\mathrm{CU})$ to 9.72 $\mathrm{kg}(\mathrm{JU})$. Tablet friability test was conducted and it measures the capacity of tablet to resist from abrasion during packaging and transportation ${ }^{26}$. The friability of studied ten brands of tablets was within accepted ranges as less than $0.5 \%$ and complied with USP-NF criteria $(\leq 1 \%){ }^{18}$. Another physical parameter is disintegration test, the disintegration times for studied ten brands of tablets were in the ranges of 3.12 to $3.70 \mathrm{~min}$, within acceptable limits. The physical parameters test results are presented in Table 1.

\subsection{Identification of amoxicillin and clavulanic acid salt within tablets}

The identification of amoxicillin and clavulanic acid salts within samples was carried out by comparing the retention data of USP reference standards and samples utilizing a validated 27 isocratic reversed phase-HPLC system at UV absorption maxima $220 \mathrm{~nm}$. The representative HPLC chromatograms for USP reference standards and a marketed product as JU (UAE) are presented in Figure 1. The sample was run for 8 min to check the absence of extraneous peaks and both drugs were eluted within $2.0 \mathrm{~min}$. The mean retention times for amoxicillin was 1.9 $\pm 0.03 \mathrm{~min}$ and for clavulanic acid lithium salt was $1.36 \pm 0.02 \mathrm{~min}$ respectively for five replicates. The $\%$ RSD for retention times of RS amoxicillin and RS clavulanic acid lithium salts was $1.72 \%$ and $1.25 \%$ respectively.

\subsection{HPLC method validation results}

The calibration curves for reference standards were constructed using eight data points comprising concentration ranged from
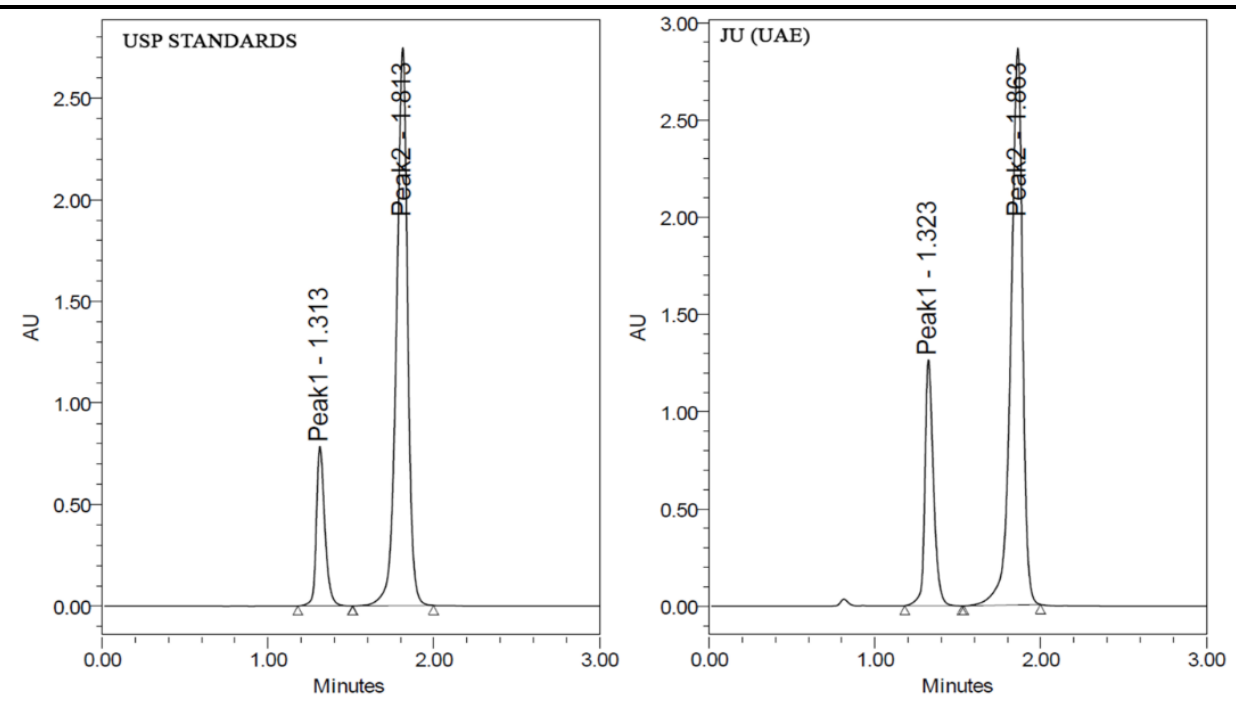

Figure 1. Isocratic RP-HPLC Chromatogram of USP Reference Standards and Tablet JU (UAE) containing of amoxicillin (Peak 2) and clavulanic acid salt (Peak 1). 


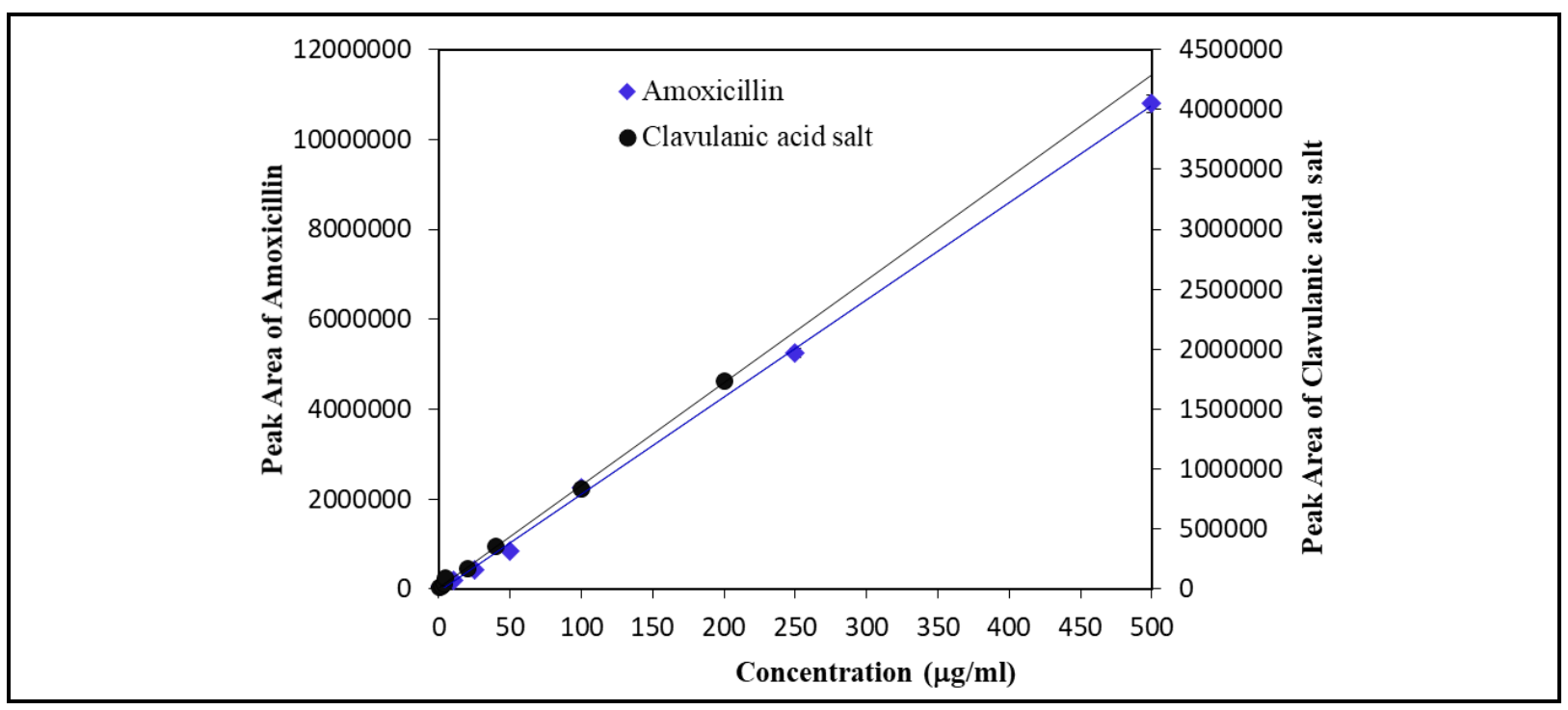

Figure 2. Detector linearity for different concentrations of USP reference standards amoxicillin and clavulanic acid lithium salt.

$1 \mu \mathrm{g} / \mathrm{ml}$ to $500 \mu \mathrm{g} / \mathrm{ml}$ for amoxicillin and from $0.4 \mu \mathrm{g} / \mathrm{ml}$ to $200 \mu \mathrm{g} / \mathrm{ml}$ for clavulanic acid salt. The mean peak areas for three replicates with SD are shown in Figure 2.

The $\%$ RSD of peak areas was ranged from 1.20 to $2.93 \%$ for amoxicillin and 0.05 to $0.89 \%$ for clavulanic acid salt respectively. The calibration curve equation for amoxicillin was $\mathrm{y}=8592.5 \mathrm{x}+4511.2\left(\mathrm{R}^{2}=0.9995\right)$ and for clavulanic acid salt was $\mathrm{y}=21602 \mathrm{x}-43812\left(\mathrm{R}^{2}=\right.$ 0.9991 ) respectively.
The suitability of the HPLC-system was evaluated by injecting three different concentrations of reference standard solution that contained amoxicillin/clavulanic acid salts. The $\%$ RSD of ten replicates for retention times was in the ranges of $0.26-0.61 \%$ (amoxicillin) and 0.19 $0.28 \%$ (clavulanic acid salts) and for peak area was $0.25-0.43 \%$ (amoxicillin) and $0.14-0.53 \%$ (clavulanic acid salts) respectively, confirmed the suitability of the HPLC system for quantitative analysis.

Table 2. Within-day, day-to-day precisions data and recovery studies of the added reference standards from AU (UK) tablet powders.

\begin{tabular}{|c|c|c|c|c|c|c|c|c|}
\hline \multirow{2}{*}{$\begin{array}{c}\text { USP } \\
\text { reference } \\
\text { standards }\end{array}$} & \multirow{2}{*}{$\begin{array}{c}\text { Concent } \\
\text { ration } \\
(\mu \mathrm{g} / \mathrm{ml})\end{array}$} & \multicolumn{2}{|c|}{$\begin{array}{c}* \text { Within-day } \\
\text { precision }\end{array}$} & \multicolumn{2}{|c|}{$\begin{array}{c}\text { *Day-to-day } \\
\text { precision }\end{array}$} & \multicolumn{3}{|c|}{ \#Recovery Studies } \\
\hline & & $\begin{array}{c}\text { Peak area } \\
\pm \text { SD } \\
(\mathbf{n}=\mathbf{3})\end{array}$ & \%RSD & $\begin{array}{c}\text { Peak area } \\
\pm \text { SD } \\
(\mathbf{n}=\mathbf{3})\end{array}$ & $\%$ RSD & $\begin{array}{c}\text { Amount } \\
\text { Added } \\
(\mu \mathrm{g})\end{array}$ & $\begin{array}{l}\text { Amount } \\
\text { Detected } \\
(\mu \mathrm{g} \pm \mathrm{SD})\end{array}$ & $\begin{array}{c}\text { \%Recovery } \\
\text { (\%RSD) }\end{array}$ \\
\hline \multirow[t]{4}{*}{ Amoxicillin } & 1 & $\begin{array}{l}275761 \\
\pm 2891\end{array}$ & 1.04 & $\begin{array}{l}25901 \\
\pm 2793\end{array}$ & 10.01 & - & - & - \\
\hline & 100 & $\begin{array}{c}2146400 \\
\pm 5023\end{array}$ & 0.23 & $\begin{array}{c}2039514 \\
\pm 14223\end{array}$ & 0.51 & 100 & $\begin{array}{l}102.48 \\
\pm 4.03\end{array}$ & $\begin{array}{c}102.48 \\
(3.93 \%)\end{array}$ \\
\hline & 250 & $\begin{array}{c}5259399 \\
\pm 14272\end{array}$ & 0.27 & $\begin{array}{c}5313961 \\
\pm 84029\end{array}$ & 1.33 & 250 & $\begin{array}{l}253.26 \\
\pm 7.59\end{array}$ & $\begin{array}{c}101.34 \\
(3.03 \%)\end{array}$ \\
\hline & 500 & $\begin{array}{c}11122959 \\
\pm 77874 \\
\end{array}$ & 0.70 & $\begin{array}{c}10911977 \pm \\
105666\end{array}$ & 0.85 & 500 & $\begin{array}{r}499.26 \\
\pm 22.57 \\
\end{array}$ & $\begin{array}{c}99.85 \\
(4.52 \%) \\
\end{array}$ \\
\hline \multirow[t]{4}{*}{$\begin{array}{c}\text { Clavulanic } \\
\text { acid salt }\end{array}$} & 0.4 & $\begin{array}{l}6848 \\
\pm 115\end{array}$ & 1.68 & $\begin{array}{l}6086 \\
\pm 757\end{array}$ & 12.45 & - & - & - \\
\hline & 40 & $\begin{array}{c}711339 \\
\pm 6370\end{array}$ & 0.89 & $\begin{array}{l}638611 \\
\pm 45424\end{array}$ & 7.11 & 40 & $\begin{array}{l}39.93 \\
\pm 1.96\end{array}$ & $\begin{array}{c}99.82 \\
(4.91 \%)\end{array}$ \\
\hline & 100 & $\begin{array}{c}1747505 \\
\pm 2771\end{array}$ & 0.15 & $\begin{array}{c}1557204 \\
\pm 98834\end{array}$ & 6.34 & 100 & $\begin{array}{l}102.21 \\
\pm 4.03\end{array}$ & $\begin{array}{c}102.21 \\
(3.94 \%)\end{array}$ \\
\hline & 200 & $\begin{array}{c}3633793 \\
\pm 21630\end{array}$ & 0.59 & $\begin{array}{l}2977081 \\
\pm 185139\end{array}$ & 6.21 & 200 & $\begin{array}{c}208.14 \\
\pm 6.49\end{array}$ & $\begin{array}{c}104.07 \\
(3.11 \%)\end{array}$ \\
\hline
\end{tabular}

$* n=3$ for each concentration for within-day precision; each concentration line for 5 days for day-to-day precision \#Recoveries of the added reference standards (amoxicillin and clavulanic acid salt) ( $n=3$ ) from AU (UK) tablet powders. 
Table 3. Assay and percent cumulative release (within $30 \mathrm{~min}$ ) of amoxicillin/clavulanic acid salts (500/125mg) from ten different tablet brands

\begin{tabular}{|c|c|c|c|c|}
\hline \multirow{2}{*}{$\begin{array}{l}\text { Products Name } \\
\text { \& Country of } \\
\text { Manufacturing }\end{array}$} & \multicolumn{2}{|c|}{$\begin{array}{c}\text { Assay } \\
\% \text { drug content/Tablet }\end{array}$} & \multicolumn{2}{|c|}{$\begin{array}{c}\text { \#Dissolution Study } \\
\text { \% Cumulative } \\
\text { Drug Release (30 min) }\end{array}$} \\
\hline & $\begin{array}{l}\text { Amoxicillin } \\
\text { Mean } \pm \text { SD } \\
(n=3)\end{array}$ & $\begin{array}{c}\text { Clavulanic acid } \\
\text { salts } \\
\text { Mean } \pm \text { SD } \\
(\mathbf{n}=\mathbf{3})\end{array}$ & $\begin{array}{c}\text { Amoxicillin } \\
\text { Mean } \pm \text { SD } \\
(n=9)\end{array}$ & $\begin{array}{c}\text { Clavulanic acid salts } \\
\text { Mean } \pm \text { SD } \\
(n=9)\end{array}$ \\
\hline AU (UK) & $98.50 \pm 1.34$ & $102.01 \pm 2.98$ & $99.55 \pm 3.01$ & $107.61 \pm 2.28$ \\
\hline CU (Austria) & $99.56 \pm 2.55$ & $97.92 \pm 3.65$ & $98.69 \pm 4.52$ & $108.51 \pm 4.13$ \\
\hline AP (Switzerland) & $95.99 \pm 1.38$ & $100.71 \pm 2.04$ & $94.05 \pm 0.48$ & $112.72 \pm 3.80$ \\
\hline CL (UAE) & $96.13 \pm 1.61$ & $108.54 \pm 3.41$ & $93.08 \pm 1.62$ & $105.29 \pm 1.01$ \\
\hline $\mathrm{ME}(\mathrm{KSA})$ & $91.66 \pm 1.68$ & $116.37 \pm 2.71$ & $99.27 \pm 3.68$ & $110.75 \pm 3.40$ \\
\hline NE (UAE) & $94.06 \pm 2.89$ & $113.85 \pm 1.27$ & $98.06 \pm 3.17$ & $110.82 \pm 4.54$ \\
\hline SW (India) & $94.09 \pm 0.81$ & $110.49 \pm 0.77$ & $96.84 \pm 1.45$ & $109.68 \pm 2.63$ \\
\hline JU (UAE) & $110.06 \pm 2.10$ & $119.60 \pm 1.80$ & $* 92.07 \pm 4.79$ & $110.11 \pm 4.78$ \\
\hline GL (UAE) & $101.79 \pm 2.28$ & $111.48 \pm 2.28$ & $* 102.10 \pm 4.16$ & $114.27 \pm 3.95$ \\
\hline AM (Jordan) & $97.60 \pm 1.37$ & $113.62 \pm 0.67$ & $* 101.36 \pm 2.31$ & $110.13 \pm 3.78$ \\
\hline
\end{tabular}

*Mean difference was significant $(\mathrm{p}<0.05)$

\#Mean result from 9 units of each brand with triplicate injections for each unit

The accuracy of the analytical method was determined using recovery studies. The recovery for amoxicillin was $99.85 \%$ to $102.48 \%$ and for clavulanic acid salt was $99.82 \%$ to $104.07 \%$ respectively (Table 2 ). The precision of analytical method was determined using four different concentration of reference standard solution that contained amoxicillin/ clavulanic acids salts. The \%RSD for within day variation for amoxicillin was from 0.23 to $1.04 \%$ and 0.15 to $1.68 \%$ for clavulanic acid salts respectively. The $\%$ RSD for five days variation was ranged from 0.51 to $10.01 \%$ for amoxicillin and $6.21 \%$ to $12.45 \%$ for clavulanic acid salts as shown in Table 2. The limit of quantification (LOQ) was defined as the amount of drug, which resulted in a peak height 10 times the standard the base line noise ${ }^{28}$. The LOQ for amoxicillin was $0.01 \mu \mathrm{g} / \mathrm{ml}$ and $0.02 \mu \mathrm{g} / \mathrm{ml}$ for clavulanic acid salts respectively.

\subsection{Quantitative analysis of marketed products}

The results of the quantitative analysis 10 brands of tablet were expressed as percent of drug present within tablets and are shown in Table 3. Amongst the four products of UAE, one of the products exhibited higher concentration of amoxicillin than other product as JU contained equivalent of $110.06 \%$ amoxicillin and lowest concentration observed in NE as $94.06 \%$, also a product of UAE. Amongst the imported product, AU (UK), contained $98.50 \%$ amoxicillin higher concentration than other imported products. The lowest concentration observed in $\mathrm{ME}$, a product of KSA that contained equivalent of $91.66 \%$ amoxicillin. However, the recorded concentration of amoxicillin within tablets were decreased in the order of: $\mathrm{JU}>\mathrm{GL}>\mathrm{AU}>\mathrm{CU}>$ $\mathrm{AM}>\mathrm{CL}>\mathrm{AP}>\mathrm{SW}>\mathrm{NE}>\mathrm{ME}$. Statistically, JU exhibited higher concentration of amoxicillin than other products $(\mathrm{p}<0.05)$, but the mean differences of JU, GL and $\mathrm{AU}$ were not significantly $(\mathrm{p}<0.05)$ different. Though, AU contained third highest concentration of amoxicillin than other products, but, the means were statistically similar with the means of AP, $\mathrm{CL}, \mathrm{SW}$ and AM. In addition, the mean value of SW, an Indian product was not statistically significant different from the means of AP (Switzerland), CL (UAE) and ME (KSA) products respectively. According to USP-NF 18 amoxicillin and clavulanate potassium tablets should contained amoxicillin and clavulanic acid salt within $90 \%-120 \%$ of the labeled amounts. In comparison with USP-NF ranges ${ }^{18}$, all the studied products contained acceptable amounts of active ingredients (Table 3 ).

The highest concentration (119.60\%) of clavulanic acid salts was observed in JU, a UAE product, whereas lowest concentration (97.92\%) observed in CU, a product of Austria. The overall results of concentration of clavulanic acid salt amongst the studied products were decreased in the order of: $\mathrm{JU}>\mathrm{ME}>\mathrm{NE} \geq \mathrm{AM}>\mathrm{GL}>\mathrm{SW}>$ $\mathrm{CL}>\mathrm{AU}>\mathrm{AP}>\mathrm{CU}$. The concentrations of clavulanic acid salt were almost equal in NE, a product of UAE and AM, a product of Jordan. The results were compared statistically (Table 3 ), though JU contained highest concentration of 


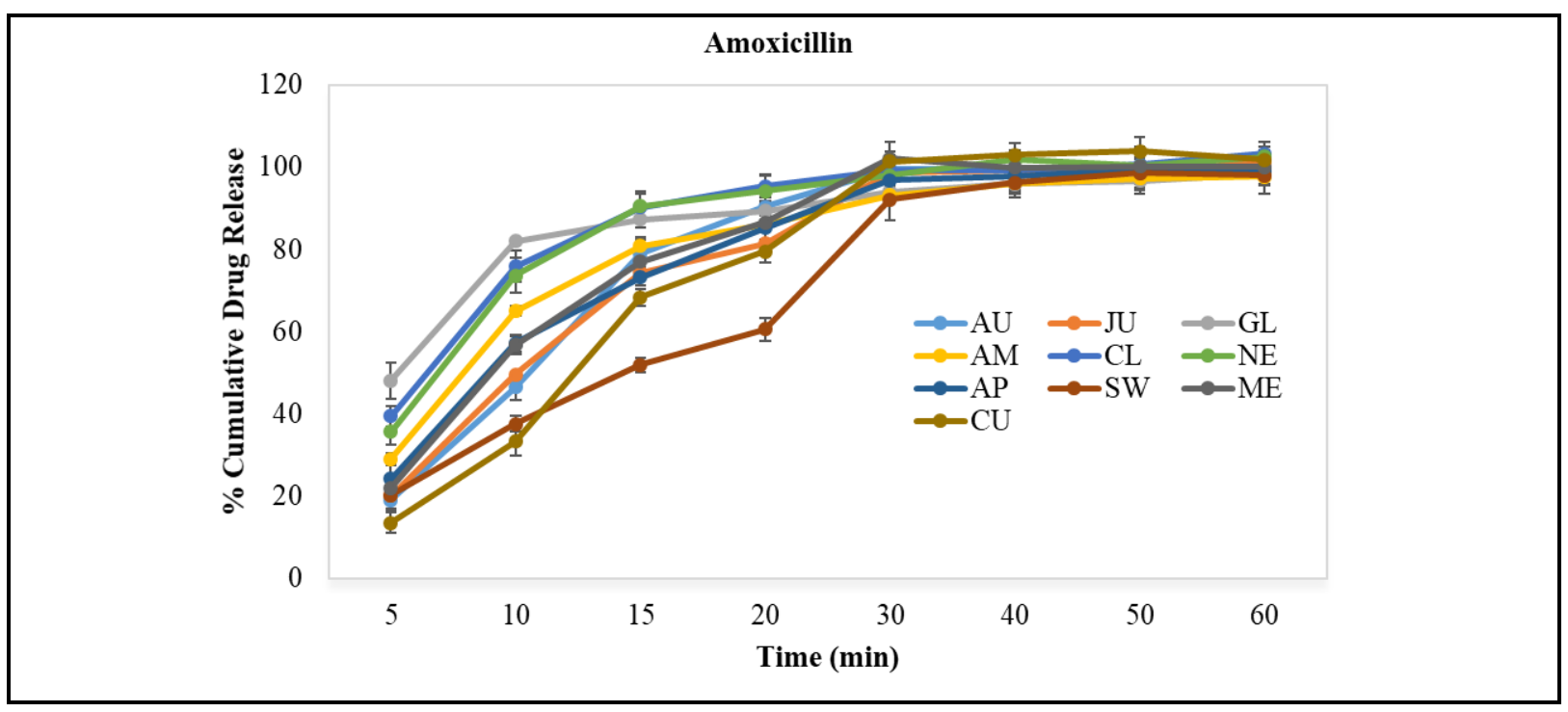

Figure 3. Comparison of dissolution profiles of amoxicillin from ten different brands of tablets contained $500 \mathrm{mg}$ amoxicillin and $125 \mathrm{mg}$ clavulanic acid salt.

clavulanic acid salt amongst the studied products, but the mean value of JU and ME was not statistically significant different $(\mathrm{p}<0.5)$. In addition, there were no statistically significant differences $(p<0.5)$ in mean values in between $\mathrm{AU}, \mathrm{CU}$ and AP; CL, SW, GL, AM and NE respectively. In comparison with USP-NF ${ }^{18}$ range for assay of tablets, all the studied products contained clavulanic acid salts within 90\% $120 \%$ ranges ${ }^{18}$.

\subsection{In vitro dissolution study results}

Table 3 represented with the \%cumulative drug release within $30 \mathrm{~min}$. According to USP-NF ${ }^{18}$, tablets should release not less than $85 \%$ of the labeled amount of amoxicillin and not less than $80 \%$ of the labeled amount of clavulanic acid in $30 \mathrm{~min}$. Amongst the local products GL (UAE) released higher amount of drugs $(102.10 \% \pm 4.16)$ and JU (UAE) released lower amount of drugs $(92.07 \% \pm 4.79)$. Amongst the imported product, AU (UK) exhibited higher amount of drug release $(99.55 \% \pm 3.01)$ and lowest drug release $(94.05 \% \pm 0.48)$ observed in AP (Switzerland). However, the overall results for cumulative amoxicillin released decreased in the order of: $\mathrm{GL}>\mathrm{AM}>\mathrm{AU}>\mathrm{ME}>\mathrm{CU}>\mathrm{NE}>\mathrm{SW}>\mathrm{AP}>\mathrm{CL}>\mathrm{JU}$. The results were compared statistically and found the mean differences were not significant $(\mathrm{p}<0.05)$ amongst the studied products except JU, GL and AM where the mean differences were significant. For cumulative release of clavulanic salts, higher release $(114.27 \% \pm 3.95)$ observed from GL a product of UAE and lower amount released $(105.29 \% \pm 1.01)$ from CL - also a product of UAE. The overall released results for clavulanic acid salts were decreased in the order of: GL (UAE) > AP (Switzerland) > NE (UAE) $\geq \mathrm{ME}(\mathrm{KSA}) \geq \mathrm{JU}(\mathrm{UAE}) \geq \mathrm{AM}($ Jordan $) \geq \mathrm{SW}$ (India) $>\mathrm{CU}$ (Austria) $>\mathrm{AU}(\mathrm{UK})>\mathrm{CL}$ (UAE). Statistically there were no significant $(p<0.05)$ mean differences amongst the studied product. In comparison with USP-NF ${ }^{18}$, all the products were complied with the official monograph for release of clavulanic acid salt from market products.

\subsection{Dissolution profile comparison results}

The dissolution study results with eight data points of 10 brands of tablets are presented in Fig. 3 and Fig. 4 respectively, where \% cumulative release of drugs are shown at 5, 10, $15,20,30,40,50$ and 60 min time intervals. Comparison of dissolution profiles for two products can be made through single-point dissolution tests, however, it is more accurate when two dissolution profiles are compared at multiple sample time points than the single point approach ${ }^{29,30}$. The dissolution profiles for each studied tablet brand were compared for amoxicillin and clavulanic acid released at different times intervals. The similarity factor $(f 2)$ and difference factor $(f 1)$ were calculated using eight data sample points and the results are presented in Table 4 . The observed $f 1$ values for amoxicillin were ranged from 0.14 to 12.17 , were within reference ranges $(0-15)$. The calculated $f 2$ 


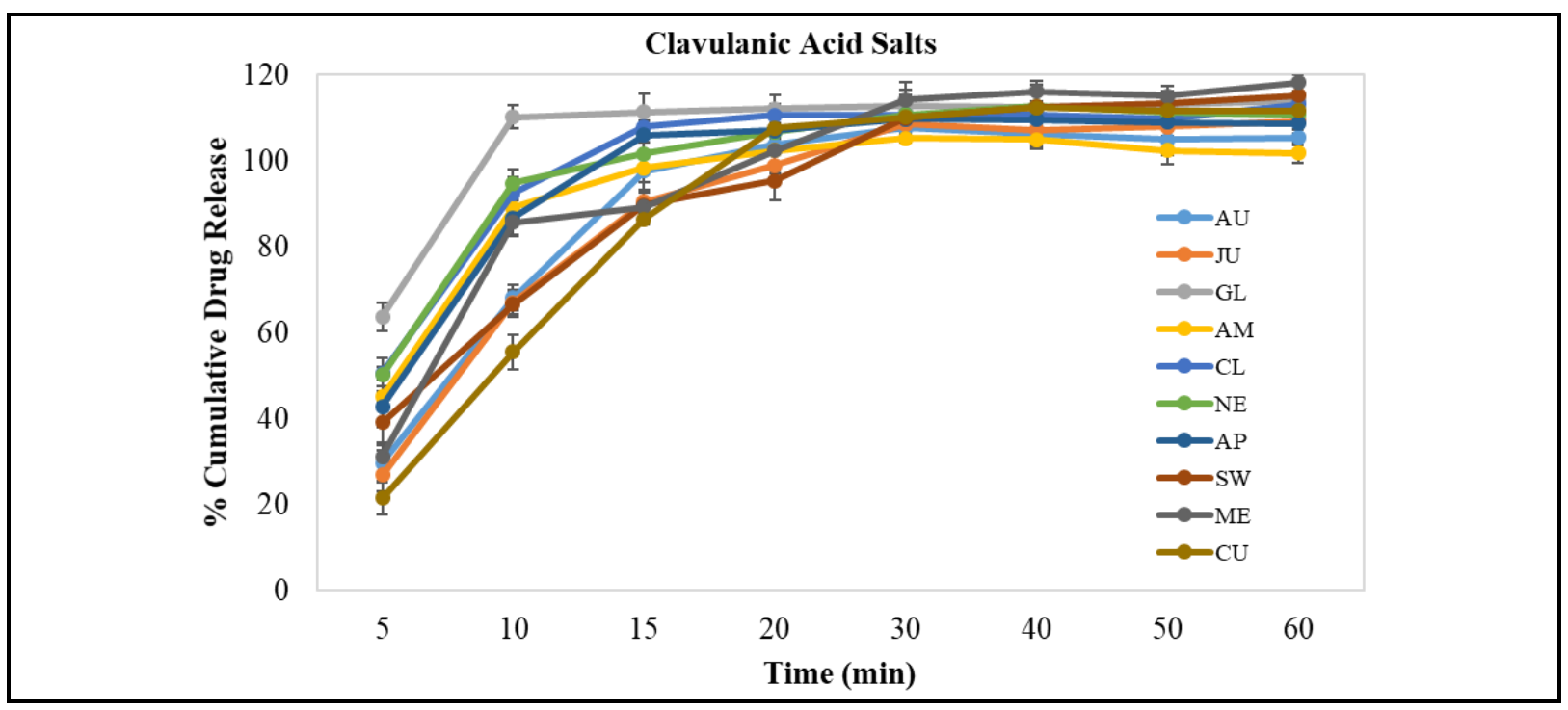

Figure 4. Comparison of dissolution profiles of clavulanic acids from ten different brands of tablets contained $500 \mathrm{mg}$ amoxicillin and $125 \mathrm{mg}$ clavulanic acid salt.

values for amoxicillin were ranged from 50.78 to 51.40 and complied with the reference ranges (50100 ). In case of clavulanic acid, the $f 1$ values exceed the reference ranges (0-15) for one product as GL (17.49), however $f 2$ value (50.69) was within reference ranges (50-100). The observed $f 1$ ranges for clavulanic acid were 0.89 to 17.49 and f2 ranges were 50.69 to 51.42 respectively.

\subsection{Microbiological study results}

Well diffusion technique was used for antibiotic susceptibility testing as this technique not only classifies resistant, intermediate and sensitive organisms but also provides a visual indication of inoculum level, presence of contamination, resistant mutants and betalactamase activity ${ }^{25,31-33}$. A clear zone of inhibition (ZI) against both Gram positive and gram negative strains was observed. All the studied products and reference standards were susceptible against $E$. coli, S. aureus and $S$. pneumonia strain but the strain, $P$. aeruginosa was resistant to the standard and all brands of tablets and did not show any inhibitory activity. The highest ZI $(48.00 \mathrm{~mm})$ observed for standard against $S$. aureus, whereas lowest ZI observed for AM against $E$. coli, and for SW against $S$. pneumonia. The ZI values amongst the studied products against $E$. coli were increased in the order of: $\mathrm{AM}(23.66 \pm 0.57 \mathrm{~mm})<\mathrm{AP}$ $(24.33 \pm 0.57 \mathrm{~mm})<\mathrm{SW}(24.50 \pm 0.50 \mathrm{~mm})<$ $\mathrm{JU}(24.66 \pm 0.57 \mathrm{~mm})<\mathrm{ME}(25.66 \pm 0.57 \mathrm{~mm}) \cong$ $\mathrm{CL} \cong \mathrm{CU} \cong \mathrm{GL}<\mathrm{AU}(26.33 \pm 0.57)<\mathrm{NE}(28.66$ $\pm 0.57 \mathrm{~mm})<$ Standard $(29.00 \pm 0.00 \mathrm{~mm})$ respectively. In comparison the ZI amongst products and standard against E. coli, there were no statistically significant $(\mathrm{p}<0.05)$ differences in between NE and standard. In comparison with reference product $\mathrm{AU}$ (UK) with other local and imported products, no significant differences $(p<0.05)$ in ZI observed with ME (KSA), CL (UAE), CU (Austria) and GL (UAE) respectively. For $S$. aureus, NE (UAE), exhibited highest antibacterial activity $(46.66 \pm 0.57 \mathrm{~mm})$ and AP (Switzerland) and GL (UAE) exhibited lowest activity $(41.66 \pm 0.57 \mathrm{~mm})$. The ZI values of standard and marketed products were compared, $\mathrm{JU}$ and NE - products of UAE exhibited statistically $(\mathrm{p}<0.05)$ similar activity with standard. In comparison with AU (UK) with other products, there were no statistically significant differences $(p<0.05)$ in activity observed with other local and imported products. The overall ZI results of studied products against $S$. aureus were increased in the order of: GL $(41.66 \pm 0.57 \mathrm{~mm}) \cong$ $\mathrm{AP}(41.66 \pm 0.57 \mathrm{~mm})<\mathrm{AU}(42.66 \pm 0.57 \mathrm{~mm}) \cong$ $\mathrm{SW} \cong \mathrm{CU} \cong \mathrm{CL}<\mathrm{AM}(43.5 \pm 0.50 \mathrm{~mm}) \cong \mathrm{ME}<$ $\mathrm{JU}(45.33 \pm 0.57 \mathrm{~mm})<\mathrm{NE}(46.66 \pm 0.57 \mathrm{~mm})<$ Standard $(48.00 \pm 0.00 \mathrm{~mm})$. The antibacterial activity against $S$. pneumonia, higher ZI observed for NE- a product of UAE and there was no statistically significant differences $(\mathrm{p}<0.05)$ in activity in comparison with standard. The lowest ZI observed for SW (India) and the overall results against $S$. pneumonia were increased in the following order: $\mathrm{SW}(30.66 \pm 0.57 \mathrm{~mm})<\mathrm{ME}$ $(31.33 \pm 0.57 \mathrm{~mm})<\mathrm{AU}(32.33 \pm 0.57 \mathrm{~mm}) \cong \mathrm{CL}$ $<\mathrm{AM}(33.33 \pm 0.57 \mathrm{~mm}) \cong \mathrm{GL} \leq \mathrm{AP}(33.5 \pm 0.50$ $\mathrm{mm}) \cong \mathrm{JU} \leq \mathrm{CU}(33.66 \pm 0.57 \mathrm{~mm})<\mathrm{NE}(35.66$ $\pm 0.57 \mathrm{~mm})<$ Standard $(36.00 \pm 0.00 \mathrm{~mm})$. 
Table 4. Calculated similarity factor $(f 2)$ and difference factor $(f 1)$ for nine brands of tablets contained amoxicillin and clavulanic acid salts.

\begin{tabular}{ccccc}
\hline $\begin{array}{c}\text { Products Name \& Country } \\
\text { of Manufacturing }\end{array}$ & \multicolumn{2}{c}{ Amoxicillin } & \multicolumn{2}{c}{ Clavulanic acid salts } \\
JU (UAE) & 2.03 & 51.40 & 0.96 & 51.42 \\
GL (UAE) & 9.41 & 50.78 & 17.49 & 50.69 \\
AM (Jordan) & 1.99 & 51.09 & 3.63 & 51.02 \\
CL (UAE) & 11.23 & 50.87 & 11.42 & 50.89 \\
NE (UAE) & 10.18 & 50.91 & 10.45 & 50.90 \\
AP (Switzerland) & 0.14 & 51.28 & 7.77 & 51.04 \\
SW (India) & 12.17 & 50.83 & 2.60 & 51.12 \\
ME (KSA) & 1.94 & 51.36 & 6.79 & 51.00 \\
CU (Austria) & 4.35 & 51.11 & 0.89 & 51.10 \\
\hline
\end{tabular}

The zone of growth inhibition obtained by the well diffusion method for standard was consistent with the MICs (Minimal Inhibitory Concentration) for all the ten brands of amoxicillin/clavulanic acid salt. The MIC values for Gram-positive bacteria were lower compared to those for Gram-negative bacteria. The MIC against Gram-negative bacteria $E$. coli was $15.63 \mu \mathrm{g} / \mathrm{ml}$ (AMOX) $/ 6.25 \mu \mathrm{g} / \mathrm{ml}$ (CLAV) for USP standards as well as for all the studied products. The USP standards and other eight products as GL, CL, AU, AP, AM, NE, JU and SW exhibited MIC 0.244375 $\mu \mathrm{g} / \mathrm{ml}($ AMOX) $/ 0.0975 \mu \mathrm{g} / \mathrm{ml}$ (CLAV) against $S$. aureus. Whereas two other products as ME and CU showed slightly higher MIC as $0.48875 \mu \mathrm{g} / \mathrm{ml}$ (AMOX) $/ 0.195 \mu \mathrm{g} / \mathrm{ml}$ (CLAV) against $S$. aureus. Against S. pneumonia, the MIC was 0.244375 $\mu \mathrm{g} / \mathrm{ml}$ (AMOX) $/ 0.0975 \mu \mathrm{g} / \mathrm{ml}$ (CLAV) for USP standards, ME, GL, AU, AP, NE, CU, JU and SW respectively, the remaining two products $\mathrm{CL}$ and AM exhibited slightly higher value as 0.48875 $\mu \mathrm{g} / \mathrm{ml}($ AMOX) $/ 0.195 \mu \mathrm{g} / \mathrm{ml}$ (CLAV) against $S$. pneumonia.

The MBC (Minimal Bactericidal Concentration) values for Gram-positive bacteria were lower when compared to those of Gramnegative bacteria. The MBC for ME, CL, AU, AP, $\mathrm{AM}, \mathrm{NE}, \mathrm{JU}$ and SW was $0.48875 \mu \mathrm{g} / \mathrm{ml}$ (AMOX) $/ 0.195 \mu \mathrm{g} / \mathrm{ml}$ (CLAV) and for GL and CU was $0.9775 \mu \mathrm{g} / \mathrm{ml}$ (AMOX) $/ 0.39 \mu \mathrm{g} / \mathrm{ml}$ (CLAV) respectively against $S$. aureus. Against other Grampositive bacteria $S$. pneumonia, the observed MBC was $0.48875 \mu \mathrm{g} / \mathrm{ml}$ (AMOX) $/ 0.195 \mu \mathrm{g} / \mathrm{ml}$ (CLAV) for eight studied products as ME, GL, AU, APNE, $\mathrm{CU}, \mathrm{JU}$ and SW respectively; and $0.9775 \mu \mathrm{g} / \mathrm{ml}$ (AMOX) $/ 0.39 \mu \mathrm{g} / \mathrm{ml}$ (CLAV) was for the other remaining two products as $\mathrm{CL}$ and $\mathrm{AM}$ respectively. However, the MBC against Gramnegative bacteria $E$. coli for different brands was similar for all the studied products $(31.25 \mu \mathrm{g} / \mathrm{ml}$ AMOX $/ 12.5 \mu \mathrm{g} / \mathrm{ml}$ CLAV) and higher value than against Gram-positive bacteria. In conclusion, not much variation of MIC and MBC values were observed amongst the studied products against Gram-positive and Gram-negative bacteria.

\section{CONCLUSIONS}

The pharmaceutical equivalence study amongst local and imported products in terms of strength, quality, purity, identity and antimicrobial susceptibility/resistance indicated that all the studied products were pharmaceutically equivalent. Amongst the imported products, the highest prices (AED 82 to 84) were for $\mathrm{AU}$ (UK) and CU (Austria) respectively, whereas the lowest price (AED 47) was for AM (Jordan). Amongst the local products, the price ranges were AED 53 to 64 only. In conclusion, local products are lower in costs and pharmaceutically equivalent in comparison with the imported products. However, bioequivalence study of studied products needs to be carried out to evaluate clinical efficacy of local and imported products in a particular diseases.

\section{ACKNOWLEDGEMENTS}

Greatly acknowledges the support of Prof. Dr. Saeed A. Khan, Dean of Dubai Pharmacy College (DPC) for carrying out this study. We are thankful to Prof. Dr. Aliasgar Shahiwala of DPC for providing USP Reference Standards.

\section{Conflict of interest (If any)}

Author declares no conflict of interest for this study

\section{Funding}

None to declare

Ethical approval

None to declare 


\section{Article info:}

Received May 23, 2019

Received in revised form August 3, 2019

Accepted September 17, 2019

\section{REFERENCES}

1. Shah SH, Shah IS, Turnbull G, Cunningham K. Cefuroxime axetil in the treatment of bronchitis: comparison with amoxicillin in a multicenter study in general practice patients. $\mathrm{Br} \mathrm{J}$ Clin Pract. 1994;48(4):185-9.

2. Matsuura M, Nakazawa H, Hashimoto T, Mitsuhashi S. Combined antibacterial activity of amoxicillin with clavulanic acid against ampicillin-resistant strains. Antimicrob Agents Chemother. 1980;17(6):908-11.

3. Reading C, Cole M. Clavulanic acid: a beta-lactamaseinhiting beta-lactam from Streptomyces clavuligerus. Antimicrob Agents Chemother. 1977;11(5):852-7.

4. Ball AP, Davey PG, Geddes AM, Farrel ID, Brookes G. Clavulanic acid and amoxycillin: A clinical, bacteriological and pharmacological study. Lancet. 1980;1: 620-3.

5. Lemke TL, Williams DA, Roche VF, Zito SW. Foe's Principle of Medicinal Chemistry. $7^{\text {th }}$ ed. Wolters Kluwer. Lippincort Williams \& Wilkins, 2013.

6. Adam D, Visser ID, Koeppe P. Pharmacokinetics of amoxicillin and clavulanic acid administered alone and in combination. Antimicrob Agents Chemother. 1982;22(3):353-7.

7. Fleisher GR, Wilmott CM, Campos JM. Amoxicillin combined with clavulanic acid for the treatment of soft tissue infections in children. Antimicrob Agents Chemother. 1983;24(5):679-81.

8. Easton J, Noble S, Perry CM. Amoxicillin/Clavulanic acid: A review of its use in the management of pediatric patients with acute otitis media. Drugs. 2003;63:311-40.

9. Pukander JS, Jero JP, Kaprio EA, Sorri MJ. Clarithromycin vs amoxicillin suspensions in the treatment of paediatric patients with acute otitis media. Pediatr Infect Dis J. 1993;12(3): 118-21.

10. Basha DM, Venkata GR, Rany S. Development and validation of clavulanic acid by negative ion mode in human plasma using LCMS/MS: Application to pharmacokinetic and bio-equvivalance study. IOSR J Appl Chem. 2016;9 (2):6-14.

11. FDA. 2005. Available from: https://www.fda.gov/ohrms/ dockets/ac/05/briefing/2005-4137B1_07_Nomenclature.pdf [Last cited on 2017 Dec 25].

12. Witkowski G, Lode H, Höffken G, Koeppe P. Pharmacokinetic studies of amoxicillin, potassium clavulanate and their combination. Eur J Clin Microbiol Infect Dis. 1982;1 (4):233-7.

13. Olanrewaju OJ, Paul AC, Olusola AM. Quality assessment of amoxicillin-clavulanate potassium tablets in Lagos, Nigeria. J Chem Paharm Res. 2012;4:5032-8.

14. Henry Nettey H, Allotey-Babington GL, Debrah P, AdiDako O, Shaick M, Kintoh I, et al. The quality and in vitro efficacy of amoxicillin/clavulanic acid formulations in the central region of Ghana. Pharmacol Pharmacy J. 2014;5:49-60.

15. Mekonnen T, Kahaliw W, Somasundaram J. In-vitro quality evaluation of different products of amoxicillinclavulanate potassium tablets. Int J of Allied Med Sci and Clin Res. 2016;4(1):10-6.
16. Balasubramanian J, Radhika N, Adinarayana G, Nandhini GA , Jothi K, Sugathri S. Regulatory prerequest for pharmaceutical products as per UAE guidelines. World J Pharmacy Pharm Sci. 2015:4(10):487-507.

17. Pateriya S, Janodia MD, Deshpande PB, Ligade VS, Talole KB, Kulshrestha T, et al. Regulatory aspects of pharmaceuticals' exports in gulf cooperation council countries. J Young Pharm. 2011;3(2):155-62.

18. USP-NF. The United State Pharmacopeia 40, National Formulary 35. The United State Pharmacopeial Convention, 12601 Twinbrook Parkway, Rockville, MD 20852. 2017; Vol 2:2792.

19. Moore JW, Flanner HH. Mathematical comparison of curves with an emphasis on in vitro dissolution profiles. Pharm Technol. 1996;20(6):64-74

20. MacFaddin JF. Media for isolation-cultivationidentification-maintenance of medical bacteria, Vol. 1, Williams and Wilkins, Baltimore, 1985.

21. Sambrook J, Russell DW. Molecular cloning - A laboratory manual. 3rd. Cold Spring Harbor, New York: Cold Spring Harbor Laboratory Press; 2001.

22. Andrews JM. Determination of minimum inhibitory concentrations. J Antimicrob Chemother. 2001;48(1):5-16.

23. Murray PR, Baron JH, Pfaller MA, Jorgensen JH, Yolken RH. Manual of clinical microbiology, 8th Ed., American Society for Microbiology, Washington, D.C. 2003.

24. Adeleke OE, Coker ME, Oluwagbohun JO, Fatoyinbo AD. Brands of ampiclox against clinical strains of Staphylococcus aureus. African J Clinical Exp Microbiol. 2010;11(1):129-36 .

25. Cheesebrough M. District laboratory practice in tropical countries Part 2. UK: Cambridge, University Press, 2000;134-43.

26. El Attug MN, Ammar A, Tunsi S, Elmjrab S, Al-Sharif $S$, Gobassa A, et al. Pharmaceutical evaluation of an augmentin brand manufactured in different countries. Am J Pharmacy Pharmacol. 2015;2(4):35-44 .

27. ICH Q2A Guidelines. 2005 Available from: http://www.ich.org/fileadmin/Public_Web_Site/ICH_P roducts/Guidelines/Quality/Q2_R1/Step4/Q2_R1__Gui deline.pdf [Last cited on 2018 March 20].

28. Hertog MGL, Hollman PCH. Optimization of a quantitative HPLC determination of potentially anticarcinogenic flavonoids in vegetables and fruits. J Agri Food Chem. 1992;40(9):1591-1598.

29. Sathe P, Tsong Y, Shah P. In vitro dissolution profile comparison: statistics and analysis, model dependent approach. Pharm Res. 1996;13(12):1799-803.

30. Shah VP, Tsong Y, Sathe P, Liu J-P. In vitro dissolution profile comparison-statistics and analysis of the similarity factor, f2. Pharm Res. 1998; 15(6):889-96.

31. Eliopoulos GM, Moellering RC. Antimicrobial combinations. In Antibiotics in laboratory medicine, 4th ed.; Lorain, V., Ed.; The Williams \& Wilkins Co.: Baltimore, MD, USA; 1996.

32. NCLS (National Committee for laboratory Standards). Methods for antimicrobial susceptibility testing for bacteria which grow aerobically. 5th ed, Approved standard M7-A5, NCCLS Wagne; 2000.

33. Bonev B, Hopper J, Parisot J. Principles of assessing bacterial susceptibility to antibiotics using the agar diffusion method. J Antimicrob Chemother. 2008;61(6):1295-301. 